\title{
The Unintended Negative Consequences of Government Actions and Initiatives in Selected Environmental, Social and Economic Domains: Opportunities for Co-construction Approaches
}

\author{
Christopher R. BRYANT'1 ${ }^{4}$ Chérine AKKARI ${ }^{2}$, Antonia D. BOUSBAINE 3 , Kénel DELUSCA 4 , \\ Oumarou DAOUDA5, Mamadou A. SARR ${ }^{6}$, Madani AZZEDDINE 7 \\ ${ }^{1}$ University of Guelph, Ontario Agricultural College, School of Environmental Design and Rural Development, Ontario, CANADA \\ ${ }^{2}$ University of Montréal, Faculty of Arts and Sciences, Montréal, CANADA \\ 3 University of Liège, Department of Geography, Laboratory LAPLEC, Liège, BELGIUM \\ ${ }_{4}$ Institute of Science, Technology and Advanced Studies of Haiti, Cap Haitien, HAITI \\ 5 United Nations Development Program, Program Analyst, Senior Technical Advisor, Brazzaville, REPUBLIC OF CONGO \\ ${ }^{6}$ Centre de Suivi Écologique, Dakar, SENEGAL \\ 7 University of Djilali Bounaama Khemis Miliana, Faculty of Social and Human Sciences, Department of Human Sciences, Khemis \\ Miliana, ALGERIA \\ E-mail: christopher.robin.bryant@rogers.com, cherine.akkari@hotmail.com, kenel.delusca@gmail.com, omardaouda@gmail.com, \\ mamadou_sarr74@hotmail.com, azzeddine.madani@univ-dbkm.dz \\ DOI: 10.24193/JSSP.2017.2.01 \\ https://doi.org/10.24193/JSSP.2017.2.01
}

K e y w o r d s: government intervention, unintended consequences, co-construction of interventions, agriculture, climate change adaptation, coastal communities

\begin{abstract}
A B S T RA C T
Governments are frequently involved in dealing with major environmental, social and economic issues, often with the stated intention of improving the situation of population directly concerned. However, many government interventions have also led to unintended negative consequences. Using selected issues particularly relating to agriculture, coastal communities and adaptation to climate change and variability, a conceptual framework is first presented. This focuses on the types of unintended negative consequences as well as their underlying causes. Some of the underlying causes relate to the lack of governments' understanding of how people in different territories have different priorities and act accordingly. A major approach for improving this situation is to develop co-construction processes leading to the creation of policies, programmes and initiatives. Co-construction involves integrating the extensive knowledge of the many legitimate actors who frequently have not been involved by governments in the development of policies, programs and initiatives. This involvement can involve citizens or their representatives, and should include the whole range of legitimate interests in what is being discussed, planned and put into action. In this article, brief reference is also made to unintended positive consequences of government action, but the focus is on the unintended negative consequences of government action. The article is based upon a wide range of research projects involving the different authors, including sequences of research projects in both developed and developing countries as well as drawing unon results from the research literature.
\end{abstract}

\section{INTRODUCTION}

Governments of all levels have been involved to various degrees in dealing with environmental, social and economic issues, e.g. the vulnerability of human activities, coastal communities and cities generalculture and industry. While many interventions have been aimed at improving the situation for the affected populations and their environments, it is also the case that many interventions have given rise to unintended 
negative consequences. The authors have undertaken research on a variety of issues in developed (Canada, France, Belgium) and developing countries (Haiti, Algeria, Senegal), with unexpected negative consequences of government interventions being frequent.

The objectives of this article are twofold:

a). To discuss the question of unintended negative consequences. Our focus is on selected major environmental, societal and economic issues. Our primary focus is on interventions in domains in which one or more of the co-authors of this article have been involved, including agricultural development, coastal communities' resilience in the face of tidal surges and storms, climate change and variability, tourism development and regional development with its implications for land use conflicts and regional disparities.

b). To develop the argument that one of the most pertinent approaches to avoiding such unintended negative consequences is by using the co-construction approach which goes substantially beyond simply planning that involves different actors. Indeed, some co-construction processes directly involve citizen mobilization and participation, including citizens who even take over managing certain initiatives and their development.

In what follows in this article, we first present the research domains of the co-authors, the length of time they have been involved in these different research domains and the principal research approaches they have used which have helped them identify the unintended negative consequences of government interventions of different types. Second, based on this research, a conceptual framework is presented drawing upon a sample of issues tackled by government intervention, the unintended negative consequences frequently generated and the factors that lead to such unintended results. Third, a number of examples are identified where such unintended negative consequences have been observed. Fourth, based upon these examples we develop some lessons for all levels of government intervention focusing on the relevance and efficiency and effectiveness of co-construction processes that can lead to more resilient actions and initiatives, policies and programs. Co-construction stands out as a major lesson to be learned and used in order to improve how environmental, social and economic issues that are being tackled are dealt with.

Co-construction processes in appropriate forms can be used at any level of government when policies, plans, programs, projects, initiatives and actions are presented and discussed because coconstruction also involves the integration as much as possible of the knowledge possessed by the many legitimate actors and segments of the population who have frequently not been involved by governments in the past in developing appropriate approaches when dealing with major environmental, economic and social issues.

\section{RESEARCH APPROACHES USED BY THE CO-AUTHORS WHO HAVE CONTRIBUTED TO THE IDENTIFICATION OF UNINTENDED CONSEQUENCES OF GOVERNMENT ACTIONS AND INITIATIVES}

It is important to recognize that the research undertaken by the co-authors was not initially intended to identify the unintended consequences of government actions. The research domains (Table 1) were aimed at other objectives but in the course of much of the research, it became apparent that government was an important actor influencing the different domains and also led to the identification of the unintended consequences of government actions and initiatives. Table 1 shows that the authors of this article have had a wide variety of research interests; some have been undertaking research for a long time, while others are more recent involving research for their graduate degrees in the last 9 to 11 years. The authors have also undertaken detailed research in a variety of jurisdictions (countries, territories or regions), including France (Île-de-France region), Belgium (Wallonia), Canada (including Quebec and Ontario), the U.S.A. (Vermont), Haiti, Algeria, Senegal, Niger and the Congo) and some have been involved in research and practical work on the ground work with the United Nations (Daouda, Délusca) and also in the mobilization of researchers internationally (Bryant through the International Geographical Union Commission on the Sustainable Development of Rural Systems (successively as Vice-President and then President from 1993 to 2006).

Table 1. Authors' research themes, principal research approaches and methodological tools.

\begin{tabular}{|c|l|l|}
\hline Authors & \multicolumn{1}{|c|}{$\begin{array}{c}\text { Research themes and number of years of } \\
\text { research by each author in each research theme }\end{array}$} & \multicolumn{1}{c|}{$\begin{array}{c}\text { Research approaches and } \\
\text { methodological tools }\end{array}$} \\
\hline \multirow{3}{*}{ Akkari, C. } & $\begin{array}{l}\text { Understanding the adaptation process to climate change } \\
\text { and variability (CCV) at the farm level (4 years) }\end{array}$ & $\begin{array}{l}\text { Public survey, interviews with farmers, government } \\
\text { representatives and key informants, focus } \\
\text { groups, statistical analyses }\end{array}$ \\
\cline { 2 - 4 } & Agricultural land use planning (4 years) & $\begin{array}{l}\text { Interviews with citizens, elected officials, key } \\
\text { informants and government representatives (different } \\
\text { levels), statistical analyses }\end{array}$ \\
\hline
\end{tabular}


The Unintended Negative Consequences of Government Actions and Initiatives in Selected Environmental, Social and Economic Domains: Opportunities for Co-construction Approaches

Journal Settlements and Spatial Planning, vol. 8, no. 2 (2017) 79-88

\begin{tabular}{|c|c|c|}
\hline \multirow{4}{*}{ Azzedine, $\mathrm{M}$. } & $\begin{array}{l}\text { Territorial development and planning at local, regional } \\
\text { and national levels (14 years) }\end{array}$ & \multirow[t]{2}{*}{$\begin{array}{l}\text { Statistical analyses, field work, interviews with key } \\
\text { actors, multi-criteria analyses }\end{array}$} \\
\hline & Sustainable development of transportation (14 years) & \\
\hline & $\begin{array}{l}\text { New forms of governance, citizen involvement in } \\
\text { decision-making ( } 5 \text { years) }\end{array}$ & $\begin{array}{l}\text { Interviews, statistical analyses, comparisons with } \\
\text { newly emerging forms of governance }\end{array}$ \\
\hline & Adaptation to CCV in agriculture and cities ( 5 years) & $\begin{array}{l}\text { Statistical analysis, field work, interviews with key } \\
\text { actors, multi-criteria analyses }\end{array}$ \\
\hline \multirow[b]{2}{*}{ Bousbaine, A. } & $\begin{array}{l}\text { Agriculture - links between agriculture in peri-urban } \\
\text { areas and the city (in Wallonia) ( } 4 \text { years) }\end{array}$ & $\begin{array}{l}\text { Targeted interviews and online questionnaires - with } \\
\text { farmers, neo-rural citizens, key actors }\end{array}$ \\
\hline & Governance processes in peri-urban areas ( 3 years) & $\begin{array}{l}\text { Interviews: upper level civil servants, politicians, } \\
\text { elected officials, local development officers and } \\
\text { designers of the Liège Food Belt, action research }\end{array}$ \\
\hline \multirow{4}{*}{ Bryant, C. R. } & Peri-urban agriculture (50 years) & \multirow{2}{*}{$\begin{array}{l}\text { Interviews with farmers, business owners, local } \\
\text { elected officials, members of parliament, focus } \\
\text { groups, forums involving a wide range of actors }\end{array}$} \\
\hline & Food security and food sovereignty (35 years) & \\
\hline & Adaptation of human activities to CCV (31 years) & $\begin{array}{l}\text { Climate change modelling, modelling economic } \\
\text { impacts on farm businesses, interviews with farmers } \\
\text { and other local and regional officials, as well as } \\
\text { representatives of pertinent ministries, focus groups, } \\
\text { forums, action research... }\end{array}$ \\
\hline & $\begin{array}{l}\text { Community and local economic development, strategic } \\
\text { development planning by and for the community } \\
\text { (citizens, collective actors) ( } 30 \text { years) }\end{array}$ & $\begin{array}{l}\text { Interviews: local elected officials, planners; focus } \\
\text { groups, citizen forums, accompanying strategic } \\
\text { development plans over many years, action research }\end{array}$ \\
\hline \multirow{3}{*}{ Daouda, O. } & $\begin{array}{l}\text { Agricultural vulnerability and capacity assessment, } \\
\text { dynamics of farmers and social systems to enhance their } \\
\text { resilience and adaptability to CCV (12 years) }\end{array}$ & $\begin{array}{l}\text { Public surveys, focus group discussions, informant } \\
\text { interviews, multicriteria and statistical analyses }\end{array}$ \\
\hline & $\begin{array}{l}\text { Innovation diffusion as a basis for analyzing the farmer } \\
\text { adoption of adaptation strategies ( } 9 \text { years) }\end{array}$ & $\begin{array}{llcc}\text { Public surveys, focus group discussions, key } \\
\text { informant interviews, Grounded Theory }\end{array}$ \\
\hline & $\begin{array}{l}\text { Environmental assessment, a decision-making tool in } \\
\text { the context of sustainable development ( } 16 \text { years) }\end{array}$ & $\begin{array}{l}\text { Public survey, focus group discussions, key informant } \\
\text { interviews. statistical analysis }\end{array}$ \\
\hline \multirow{4}{*}{ Delusca, K. } & $\begin{array}{l}\text { Climate change impacts assessment (agriculture, water, } \\
\text { coastal zones) (16 years) }\end{array}$ & $\begin{array}{l}\text { Statistical analysis, modelling, and ethnographic } \\
\text { techniques (interviews, focus groups) }\end{array}$ \\
\hline & $\begin{array}{l}\text { Vulnerability assessment (agriculture, water, coastal } \\
\text { zones) (10 yrs) }\end{array}$ & $\begin{array}{l}\text { Statistical and multicriteria analyses, modelling, and } \\
\text { ethnographic techniques (interviews, focus groups) }\end{array}$ \\
\hline & Bioclimatology, crop modelling (11 years) & $\begin{array}{l}\text { Crop model evaluation, crop yields projections, } \\
\text { development of agro-climatic indicators }\end{array}$ \\
\hline & Agro-environmental policies assessment (11 years) & Ethnographic techniques, impacts assessment \\
\hline \multirow{3}{*}{ Sarr, M. A. } & $\begin{array}{l}\text { Climate characterization, and modelling, evaluation of } \\
\text { climate extremes ( } 16 \text { years) }\end{array}$ & $\begin{array}{l}\text { Statistical analysis of climate data, detection of } \\
\text { extremes, calculation of signals of climate change, } \\
\text { techniques for scale reduction }\end{array}$ \\
\hline & $\begin{array}{l}\text { Pastoral unit biophysical characterization and } \\
\text { management plan development ( } 5 \text { years) }\end{array}$ & $\begin{array}{l}\text { Field data collection, focus groups, informant } \\
\text { interviews, multi-criteria and statistical analyses }\end{array}$ \\
\hline & $\begin{array}{l}\text { Agricultural vulnerability and capacity assessment, the } \\
\text { dynamics of farmers and social systems to enhance } \\
\text { resilience and adaptability to CCV ( } 9 \text { years) }\end{array}$ & $\begin{array}{l}\text { Public surveys, focus group discussions, informant } \\
\text { interviews, multicriteria and statistical analysis }\end{array}$ \\
\hline
\end{tabular}

\section{THE UNINTENDED CONSEQUENCES OF GOVERNMENT ACTIONS AND INITIATIVES IN RELATION TO MAJOR ENVIRONMENTAL, SOCIAL AND ECONOMIC ISSUES}

First a conceptual framework (Fig. 1) is presented based on three components:

1). The policies, plans, programs, projects, initiatives and actions put in place by governments;

2). The unintended consequences of such interventions, both negative and positive;

3). The factors that influence the creation of unintended negative and positive consequences.

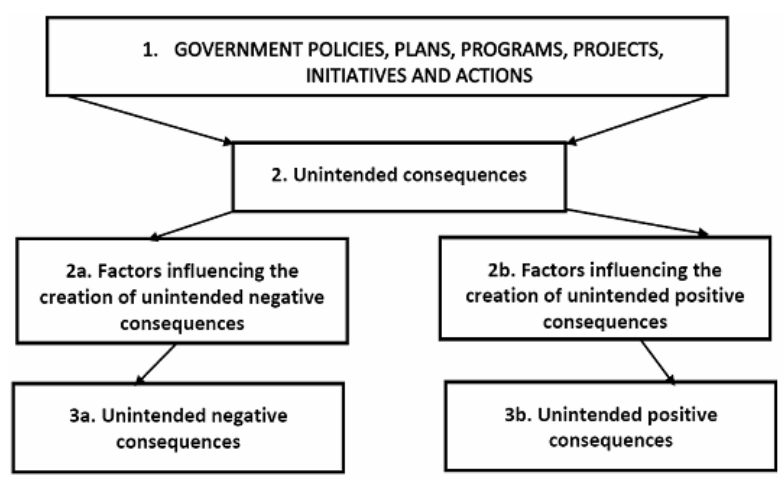

Fig. 1. The unintended consequences of government policies, plans, programs, projects, initiatives and actions. 
3.1. Policies, plans, programs, projects, initiatives and actions

Some of these have specific objectives associated with economic issues but they may also generate unintended environmental consequences (e.g. protection of farmland from suburban and exurban development and support for global agricultural competitiveness [1] which can generate major environmental issues regarding water pollution) [2], [3]).

Another example has objectives relating to economic issues associated with employment accessibility and regional development and has involved decisions to improve accessibility in large cities through increasing the capacity of major roads, often giving rise to the negative consequence of actually increasing the density of road traffic in the long term and creating a greater concentration of pollution, as well as undermining the economic viability of many smaller municipalities in remote regions because many people from these remoter areas have felt forced to migrate to the larger cities to find better employment. This has been the case of the initiatives that have attracted more people from Northern Ontario, for example, to move to the Toronto agglomeration, and this has been repeated in many countries.

Others deal with specific environmental issues (e.g. protection of specific ecosystems and their landscape representations including the human activities which have partially forged the landscapes to be protected, e.g. humanized landscapes [4]; or the installation of protective infrastructure to limit coastal community vulnerability - if not done adequately this can even increase vulnerability and create even more serious environmental and social issues).

\subsection{Unintended consequences}

Unintended negative consequences include environmental consequences such as water pollution related to policies that have encouraged the development of globally competitive and capitalist or productivist agriculture; or programs to support adaptation to climate change but which are inadequate either in terms of the amount of support provided or the nature of the support, leading to maladaptation (economically and socially) especially in poorer developing countries. Some crop insurance program supported by governments can also lead to maladaptation in relation to the various stressors such as climate change and variability.

Negative unintended consequences can also involve social and cultural consequences such as the creation of social and cultural inequalities (e.g. for native communities) following policies and programs that favor public investment in large metropolitan centres.

Political unintended negative consequences can also be observed such as the unanticipated changes when there is a change in government or even certain political leaders and when the new government or leaders are not content with what previous governments or leaders have initiated, even if other actors consider these initiatives to have been very successful.

Unintended positive consequences can include environmental consequences when for example protecting farmland can also open the way for maintaining and encouraging many people to appropriate the many other functions of agricultural land and farm activities, such as the conservation of heritage landscapes and conserving ecosystem services or functions that farmland and farming can support under certain circumstances. All of this can have positive consequences for citizens and other actors who have appropriated the value of these multiple environmental functions and which thus facilitates their conservation through conservation of farmland and farm activities.

Unintended positive social, cultural and economic consequences can emerge potentially when agricultural heritage lands are protected and when this 'new' resource becomes useful in the development of agritourism and other related leisure activities, especially near urban centres [4].

Unintended positive economic consequences can also be associated with the social and cultural unintended consequences through the development of additional income opportunities for farmers and other rural residents.

Unintended positive political consequences can also develop when various government interventions to set up infrastructure such as dams create resistance and leads to the mobilization of citizens and actors, which ultimately leads to the establishment of a co-construction process thus modifying the role of government (which we consider to be essentially positive!).

3.3. Factors involved in policies, programs, plans, actions, projects and initiatives giving rise to unintended negative consequences

The following is a non-exhaustive list of factors that contribute to explaining why unintended negative consequences can result from various government interventions:

- lack of understanding by the government authorities of the real issues involved;

- lack of a holistic approach to a specific issue, be it an environmental issue, or a social, cultural, economic or political issue; 
- lack of understanding by government of how citizens (individuals, families, business owners ...) who may be targeted by various government interventions - actually take decisions. Also, some governments have a lack of appreciation of the multiple interests of the political actors (at all levels) especially those who manage specific government intervention; in particular, this includes the personal objectives of politicians, project managers and even the people who are affected by government interventions; this simply reflects the reality that actors' priorities vary and may be more influenced by personal interests rather than by the environmental, social or economic objectives of the initiatives [5];

- misunderstanding of the appropriate roles for government depending upon the type of government intervention; the appropriate roles can range from proactive roles where government does in fact adopt socalled leadership roles to those where they adopt support roles. A priori, proactive roles are not necessarily better than support roles;

- support roles can include providing financial support for different actions, initiatives or projects in the context of different policies and programs; however, it can be argued that simply providing financial support is generally inadequate particularly when dealing with people (citizens), businesses and even local and regional municipal elected officials and their professional staff. What appears to be necessary is to provide appropriate counselling. This may not come directly from government or one of its agencies (since they may not enjoy the trust of the people) but can also come from the private sector and business associations or development officers supported by local and regional municipalities. Providing such appropriate counselling through non-governmental organizations is simply a recognition that central governments and their agencies are often considered too far removed from the realities of citizens, business owners and managers to be worth listening to; however, governments can still play an important role in supporting other actors who are closer to the interests of the people involved;

- it is possible that some unintended negative consequences reflect conflicts between the priorities of different administrators, politicians and technical specialists and depending upon the real power of each person, these conflicts may lead to unexpected consequences. And the positions of technical specialists may not even be taken into account. Political and personal priorities may take over;

- to ensure an appropriate application of a government intervention, it is important to have an appropriate follow-up of how these interventions have been planned and implemented and whether the results are what were intended; without this follow-up, certain unintended negative consequences may not be detected soon enough.

\section{EXAMPLES OF UNINTENDED NEGATIVE CONSEQUENCES}

A number of examples are briefly presented, and just a few of the unintended negative consequences are noted for each.

\subsection{Farmland protection policies and support for globally competitive or capitalist agriculture}

a). A significant volume of the legislative activity that has led to laws for the conservation of high quality agricultural land has in effect gone even further and led to rules and regulations in land use planning that have favoured large scale capitalistic farm operations. Pertinent examples of this in Canada are the laws established in the Provinces of British Columbia (1973) and Québec (1978); while not based on a specific law for the protection of agricultural land, the Province of Ontario adopted strong advice to regional municipalities in 1978 that effectively led to the same situation [6]. Similar observations can be made about legislation for protecting farmland in several U.S. States. Despite this important legislation, farmland of high quality has continued to be removed from agricultural use by governments (local, regional and senior governments) to permit residential and industrial development.

b). Recent reports have also highlighted the unintended consequences of agricultural policies and biotechnology policies in the US (e.g. [7], [8].

c). Water pollution can increase following government support for this 'modern' agriculture with its focus on competitiveness. Depending upon the circumstances, modern productivist agriculture can even lead to mud slides, e.g. with larger fields on slopes. This is the case in Wallonia, Belgium, in the Province of Hainault (municipality of Courcelles) where the most recent storms led to mud slides causing extensive damage to housing. The municipality has attempted to remedy this situation by calling upon help from farmers [9].

d). Reduction of ecosystem services, both in relation to environmental issues (e.g. water pollution and health concerns about the quality of certain food products) and landscape values [10].

e). There is a common perception that Africa hosts large amounts of vacant farmland. This agricultural potential is somehow neglected or underused as many African countries fail to achieve food self-sufficiency as a result of the negative effects of climate change and variability combined with a lack of adequate and appropriate investment in farming and food production. Many African governments are implementing investment policies in agriculture in order to attract investors [11]. One positive consequence of these policies is the rise of farm communities' 
resistance and mobilization; this has created a new dynamic in community mobilization in several countries and territories whereby new strategies to challenge corporations and governments are being launched [12]. Nevertheless, we must still recognize that the unintended negative side of these investment policies in agriculture have resulted in potential negative environmental and social impacts such as monoculture and loss of biodiversity, loss of forests and pastures, increased competition for water resources [13] as well as an increase in land scarcity for smallholders [14]. Another example is the case of the Dominion Farms' land grab in Nigeria where farmers in Taraba State refused to give up their lands for a massive rice plantation project backed by the G8 [15].

\subsection{Adaptation of human activities to climate change and variability}

The difficulties of ensuring that pertinent adaptation strategies are adopted effectively include:

- lack of understanding of what drives the decision-makers (in families, businesses, in communities) in terms of what their priorities are (which can vary substantially between jurisdictions and territories) [16], [17]; this is likely to become very significant in the support of adaptation (and mitigation) strategies following COP21 because of the rapid emergence of a major preoccupation in an increasing number of countries with the rise of terrorist actions ... what is more important to deal with first - terrorist actions or adaptation to climate change and variability and mitigation of greenhouse gas emissions?

- providing financial support alone to support adaptation strategies is not enough, it is what the adaptation strategies consist of and how well they are constructed to take account of the local and regional circumstances that makes the difference.

\subsection{Vulnerability of coastal communities to climate change and variability including tidal surges, extreme storms and severe flooding of rivers (and nearby communities)}

There are a number of difficulties in trying to plan to reduce vulnerability and increase community resilience to flooding and other disastrous effects:

- government is not always ready to invest in appropriate protective infrastructure (e.g. in a number of East coast communities in the UK recently [18]; they may invest but not always adequately;

- building solidarity among different segments of the community frequently meets with difficulties;

- barriers to integrating vulnerability reduction and building community solidarity into overall development planning processes [18], [19], [20];
- coastal community adaptation and specifically adapting to Sea Level Rise (SLR) means that several trade-offs between environmental, economic, social and cultural values have to be made (e.g. which coasts to protect and which to abandon) [21]. For instance, minimizing the number of trade-offs could be accomplished by combining several adaption strategies, e.g. as in the Netherlands where human interventions were considered in a broader, more holistic context with natural values being weighed against socioeconomic interests, giving rise to back-to-nature approaches in which the conservation of nature was given priority [22]. In Senegal, a developing country, flooding has been an issue for a number of coastal towns and various attempts have been made to reduce their vulnerability through putting in place diversion canals as well as other actions. However, in some cases the danger has actually been accentuated [23]. Furthermore, when residential development or other developments have been planned in coastal communities, inadequate attention has often been paid to the frequency of tidal surges and the magnitude of sea level rise in areas where such planned development has taken place.

\subsection{Gender-based issues and adaptation to climate change and variability}

In many countries, especially developing countries, women, more than men, are dependent on internal village groups, as opposed to organizations operating at regional or national levels (this is not necessarily disadvantageous, but it can hinder collaborative participation with other governments) [24]. It is important that government interventions to encourage and support appropriate adaptation to climate change take account of such differences, otherwise actions could actually increase the differences between men and women (i.e. lead to another unintended negative consequence).

Lack of knowledge on adaptation and strict technological preferences and aesthetic aspects (e.g. some women may prefer palatable and nutritious plant varieties which may not be drought resistant, leading to competition and conflicts with crop producers) [25].

\section{LESSONS WITH A FOCUS ON CO- CONSTRUCTION}

Overcoming a lack of understanding of decision-making processes in different jurisdictions and territories is a major challenge. Sometimes this has been reflected in central governments attempting to parachute the same set of solutions or strategies into very different municipalities and regions without appreciating the specificities of different jurisdictions, their cultures and how different segments of the 
population may perceive differentially the issues and priorities. Even worse in some respects is the attempt by developed countries to try to influence developing countries to undertake specific initiatives and projects by using Western technologies when the target territories do not necessarily have the capacity or culture to integrate such technologies into their activities.

A better understanding essentially requires a much greater knowledge of the values and priorities of different segments of the population in different jurisdictions and territories. The 'one size fits all' approach is not adequate, even in the context of different regions in the same developed country.

This implies the need to engage different actors and representatives of the different segments of the population and of the business community all of whom have legitimate interests in what government at all levels undertakes in the name of improving the situation for society (Fig. 2).

1. COMPONENTS OF CO-CONSTRUCTION OF GOVERNMENT INTERVENTIONS

Involvement of the range of legitimate actors

\begin{tabular}{|c|c|c|c|c|}
\hline $\begin{array}{c}\text { 2a. } \\
\text { Elected officials } \\
\text { (all levels, } \\
\text { depending on } \\
\text { the issue being } \\
\text { tackled) }\end{array}$ & $\begin{array}{c}\text { 2b. } \\
\text { Government } \\
\text { professionals } \\
\text { including civil } \\
\text { servants, } \\
\text { planners, } \\
\text { program } \\
\text { directors }\end{array}$ & $\begin{array}{c}\text { 2c. } \\
\text { Citizens, } \\
\text { farmers, } \\
\text { business } \\
\text { owners, } \\
\text { managers, and } \\
\text { employees }\end{array}$ & $\begin{array}{c}\text { 2d. } \\
\text { Nongovernment } \\
\text { actors, including } \\
\text { environmental, } \\
\text { farmer and } \\
\text { neighbourhood } \\
\text { associations }\end{array}$ \\
\hline
\end{tabular}

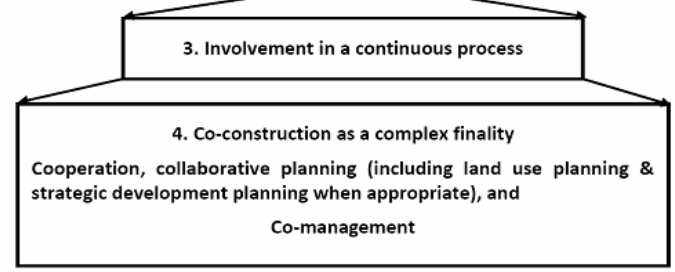

Fig. 2. Components of Co-construction of government interventions.

How this can be achieved also varies substantially between different jurisdictions and territories. It is suggested that the overall solution is to develop a set of co-construction processes (of policies, programs, actions, initiatives, projects and plans) which involve a much broader range of actors than simply political and professional actors. These co-construction processes inevitably involve the integration of traditional and local knowledge which is often cast aside by senior government and its officials. However, not all regions, territories or countries at a specific point in time have the appropriate set of cultural values to undertake or support real co-construction processes (Fig. 2).

In the European context, it has been emphasized [26] that public and corporate actors are faced with pressing questions concerning innovation policy and the return on public and private investment in innovation, particularly at the local and regional level. It has also been argued that although there have been improvements in refining the modelling of spatial externalities, studies based on the latter nevertheless still fail to offer a reliable picture of the diverse dimensions of localized innovation processes and dynamics [26]. As a result, the authors conclude that there is a need to take better account of local contexts and firms' strategies, which requires a real acknowledgment of the multi-scale dimension of interventions. In Belgium, and specifically in Wallonia, since 2012, a group of actors of civil society have focused on the supply of food. This innovative concept called Ceinture Aliment Terre (the Food Land Belt) of Liège is in the process of being constructed as an innovative system, which will allow the population of the Province of Liège to be fed by foodstuffs grown directly on the farmlands of the Province. Since July 2016, the Walloon Government (Ministry of Agriculture) has supported this initiative via the establishment of the Hall de Relais Agricoles (Agricultural Linkages Hall), a project to encourage the bringing together of farm producers and consumers to feed the population with healthy produce, given that the negative externalities of productivist agriculture have been documented and recognized by many studies and ultimately even by many public authorities [27].

Co-construction can be regarded as a way of avoiding having recourse to environmental mediation in many situations. Co-construction can be used to define policies, plans, programs, and projects, initiatives and actions; potentially the initial move towards a co-construction process can be made by government (at any level) or by other actors. At local and regional levels, co-construction can also be pursued by introducing discussions involving citizen and other actor participation; this participation requires generally putting in place effective mobilization processes without which real participation and the integration of traditional and local knowledge are less likely to succeed [28], [29], [30], [31] and co-construction is based on a continuous process ideally involving cooperation, collaborative planning and comanagement (Fig. 2) - not always simple to put in place given the cultures of many governments.

Some of these ideas can be linked to a discussion of the COP21 results and putting them into effect. For instance, emerging from the COP21 international negotiations in December 2015, some important decisions were made regarding providing financial support to developing countries to develop and integrate actions to reduce GHG emissions and also to support important adaptation initiatives. However, it can be argued that money alone is not adequate to ensure the effective construction and adoption of different strategies for mitigation and adaptation. It could be argued that the next steps could (and should?) 
be the creation of a specific mechanism that favours the participation of civil society with one of the most important plusses being to ensure that local and traditional knowledge can be integrated into the fight against climate change. Not only would this help substantially in the development of appropriate strategies of mitigation and adaptation but it could help directly in the implementation of the international agreement at the national levels.

To pick up again on the example of the Ceinture Aliment Terre of Liège, this platform has led to the creation of the project Companions de la Terre (Companions of the Land) which is founded on the basis of small-scale farms practicing agroecology. This project was retained as one of the 21 inspiring projects during the Paris Summit of 2015 [32].

\section{CONCLUSION}

In conclusion, we have to emphasize the importance of many unintended negative consequences of government interventions when it comes to dealing with major environmental, social or economic issues. These unexpected negative consequences can affect the environment, our social system and our economy. We have provided a list of some of the most important factors that have led to this unfortunate situation. One of the most important factors is that specific interventions are often not set in a holistic context which would allow government actors involved to gain a better understanding of what other consequences might arise.

Another major factor is the lack of understanding of the decision-making processes of people (such as farmers, citizens and business managers and owners, which inevitably involve multiple interests, different priorities and temporal horizons and therefore the intended consequences are not always observed because, for instance, some decision-makers have other priorities which they consider to be much more important to them in the short to medium term). And of course, a final major factor is the fact that different territories, communities and cities even in the same country have their own specificities and parachuting a standard strategy or project into many different territories, communities and cities is asking for trouble!

This all puts the emphasis on having a holistic and realistic vision of the issue that government intervention is aimed at, but also, of bringing together different actors and representatives of the different legitimate segments of interest (for example in a community, region or city) together to discuss the issue and to move towards a co-construction process. This is easier said than done because this entails generally a very different approach certainly at the national level by the political actors than has been the case in the past. 86
As a final note, we add that there are also unintended consequences of NOT TAKING certain actions or putting in place pertinent public policies and programs even when our knowledge tells us that there is a need to tackle certain phenomena. As an example, we can suggest the lack of action for many coastal communities or other communities subject to flooding even when flooding has already affected other communities in the same region at other times.

\section{REFERENCES}

[1] *** PAC (2017), Politique Agricole Commune [Common Agricultural Policy] (2016), Available at: http://www.vie-publique.com.fr/.../qu'est-ce-quepolitique-agricole-commune-pac. Last accessed: August 17, 2017.

[2] Mérenne-Schoumacker, B. (2007), L'avenir des zones d'activités en Wallonie. Réflexions et propositions, [The future of activity zones in Wallonia: Reflections and proposals], In: Territoires en mouvement, vol. 3, Université de Lille Sciences et Technologies, France, pp. 3-14.

[3] Halleux, J.-M., Brück, L., Mairy, N. (2002), La périurbanisation résidentielle en Belgique à la lumière des contextes suisse et danois: enracinement, dynamiques centrifuges et régulations collectives [Residential peri-urbanisation in Belgium from Dutch and Danish contextual perspectives: fundamental bases, centrifugal dynamics and collective regulations], In: Belgéo, (4), Royal Academies for Science and the Arts of Belgium, Comité national de Géographie and Royal Society of Geography of Belgium, Belgium, pp. 333-354. [4] Domon, G. [editor] (2009), Le paysage humanisé au Québec [Humanized landscapes in Quebec], Les Presses de l'Université de Montréal, Canada, pp. 368.

[5] Bryant, C. R., Bousbaine, A. D., Akkari, C., Daouda, O., Delusca, K., Épule, T. E., DrouinLavigne, C. (2016), The roles of governments and other actors in adaptation to climate change and variability: The examples of agriculture and coastal communities, In: AIMS Environmental Science, vol. 3, issue 3: Aims Press, U.S.A., pp.326-346.

[6] Bryant, C. R., Russwurm, L. H. (1982), North American farmland protection strategies in retrospect, In: GeoJournal, vol. 6, issue 6 (Special issue: Farmland preservation in North America), Springer, The Netherlands, pp. 501-11.

[7] Zivin, J. S. G., Perloff, J. M. (2012), An overview of the intended and unintended effects of U.S. agricultural and biotechnology policies, In: Zivin, J.S.G. and Perlof, J.M. (editors), The Intended and unintended effects of U.S. agricultural and biotechnology policies, University of Chicago Press, U.S.A., Chapter 1, pp. 1-12. Available at: http://www.nber.org/chapters/c12104.pdf

Last accessed: August 17, 2017. 
The Unintended Negative Consequences of Government Actions and Initiatives in Selected Environmental, Social and Economic Domains: Opportunities for Co-construction Approaches Journal Settlements and Spatial Planning, vol. 8, no. 2 (2017) 79-88

[8] Melillo, J. M., Gurgel, A. C., Kicklighter, D. W., Reilly, J. M., Cronin, T. W., Felzer, B. S., Paltsev, S., Schlosser, C. A., Sokolov, A. P., Wang, X. (2009), Unintended environmental consequences of a global biofuels program. MIT joint program on the science and policy of global change. Report No. 168, pp. 34. Available at: http:// globalchange.mit.edu/files/document/MITJPSPGC_Rp t168.pdf_Last accessed: August 17, 2017.

[9] Sudinfo.be (2016), Actualité: Inondations: Les coulées de boue inquiètent les agriculteurs [News: Floods: Mud slides that concern farmers] 3/6/2016. Available at: http://www.sudinfo.be/1589021/article/ 2016-06-03/inondations-les-coulees-de-boue-

inquietent-les-agriculteurs, Last accessed: August 17, 2017.

[10] Bryant, C. R. (2015), Agriculture and food, In: B. Mitchell (editor), Resource and Environmental Management in Canada $5^{\text {th }}$ Edition. Chapter 10, Oxford University Press, Canada, pp. 246-266.

[11] Friis, C., Reenberg, A. (2010), Land grab in Africa: Emerging land system drivers in a teleconnected world, GLP Report No. 1. GLP-IPO, Copenhagen, Denmark.

[12] GRAIN (2016), Against the grain. The global farmland grab in 2016. How big, how bad? Available at: http://www.grain.org/article/categories/13-againstthe-grain. Last accessed: August 17, 2017.

[13\} *** UNEP (United Nations Environment Programme), (2011), Available at: http://na.unep.net /geas/getuneppagewitharticleidscript.php?article_id=6 6. Last accessed: August 17, 2017.

[14] Jayne, T. S., Chamberlin, J., Traub, L., Sitko, N., Muyanga, M., Yeboah, K., Nkonde, C., Anseeuw, W., Chapoto, A., Kachule, R. (2015), Africa's changing farmland ownership: causes and consequences. Paper presented at the 2015 AAEA \& WAEA Joint Annual Meeting, July 26-28, 2015, San Francisco, U.S.A.

[15] Environmental Rights Action / Friends of the Earth Nigeria | Center for Environmental Education and Development (CEED) (2015), Dominion farms' land grab in Nigeria. Farmers in Taraba State refuse to give up their lands for massive rice plantation project backed by the G8. (28 January 2015), Available at: https://www.grain.org/article/ entries/5126-dominion-farm-s-land-grab-in-nigeria.

Last accessed: August 17, 2017.

[16] Daouda, O., Bryant, C. R., Akkari, C. (2015), Social networks and the diffusion of innovations, towards a critical partnership for a successful adaptation strategy: A case study of agriculture in Southwestern Quebec, In: International Journal of Climate Change: Impacts and Responses, vol. 6, issue 34, Common Ground Publishing Journals, China, pp. 3758.
[17] Bryant, C. R., Delusca, K., Sarr, M. A. (eds.) (2016), Agricultural Adaptation and Climate Change. Springer, The Netherlands, pp. XIII, pp. 234.

[18] Bousbaine, A. D., Bryant, C. R. (2015), Les défis des communautés côtières pour rehausser la résilience et leur capacité à faire face aux intempéries climatiques [The challenges of coastal communities to increase their resilience and capacity to confront climatic disturbances], In: Vertigo, Special Issue, November 2015, Université du Québec à Montréal, Canada. Available at: http://vertigo.revues.org/16608, Last accessed: August 17, 2017.

[19] Füssel, H., Klein, R. J. T. (2006), Climate change vulnerability assessments: An evolution of conceptual thinking, In: Climatic Change, vol. 75, issue 3, Springer, The Netherlands, pp. 301-329.

[20] Gutierrez, É. (2015), Bilan sur la gestion des inondations de 2014 dans le Var : Hyères et la Londeles-Maures, [Assessment of the management of the 2014 floods in the Var : Hyères and Londe-les-Maures], Département de Géographie, Université de Montréal, Étude de cas (Professional Masters Case Study), pp. 105.

[21] Bijlsma, L., Ehler, C. N., Klein, R. J. T., Kulshrestha, S. M., McLean, R. F., Mimura, N., Nicholls, R. J., Nurse, L. A., Pérez Nieto, H., Stakhiv, E. Z., Turner, R. K., Warrick, R. A. (1996), Coastal zones and small islands, In: Watson, R.T., Zinyowera. M.C., Moss, R.H. (editors), Climate change 1995 impacts, adaptations and mitigation of climate change: scientific-technical analyses, Contribution of Working Group II to the Second Assessment Report of the Intergovernmental Panel on Climate Change, Cambridge University Press, U.K., pp. 289-324. Available at: http://na.unep.net/geas/getuneppagewitharticleidscrip t.php?article_id=66 Last accessed: August 17, 2017.

[22] Bruin de, K., Dellink, R., Ruijjs, A., Bolwidt, L., van Buuren, A., Graveland, J., de Groot, R. S., Kuikman, P. J. Reinhard, S., Roetter, R. P., Tassone, V. C., Verhagen, A., van Ierland, E. C. (2009), Adaptation to climate change in the Netherlands: An inventory of climate adaptation options and ranking of alternatives, In: Climatic Change, vol. 95, issues 1-2, Springer, The Netherlands, pp. 23-45.

[23] *** Ministère de l'État de l'Environnement au Sénégal (2015), Environnement marin et côtier [Marine and coastal environments], In: Rapport sur l'Environnement au Sénégal [Report on the environment in Senegal], Édition 2015, Chapter 4, pp. 64-67.

[24] Perez, M., Jones, E. M., Kristjanson, P., Cramer, L., Thornton, P. K., Forch, W., Barahona, C. (2015), How resilient are farming households and communities to a changing climate in Africa? A gender-based perspective, In: Global 
Environmental Change, vol. 34, Elsevier, The Netherlands, pp. 95-107.

[25] Fisher, M., Carr, E. R. (2015), The influence of gendered roles and responsibilities on the adoption of technologies that mitigate drought risk: The case of drought-tolerant maize seed in Eastern Uganda, Global Environmental Change, vol. 35, Elsevier, The Netherlands, pp. 82-92.

[26] Massard, N., Autant-Bernard, C. (2015), Editorial: Geography of innovation: new trends and implications for public policy renewal, Regional Studies, vol. 49, issue 11, Taylor \& Francis, United Kingdom, pp. 1767-1771.

[27] Bousbaine, A. D., Bryant, C. R. (2016), Ceinture-Aliment-Terre, système innovant pour nourrir la population [Food Land Belt, an innovative system to feed the population], Paper presented at the 24th Colloquium of the IGU Commission on the Sustainability of Rural Systems, Université de Liège, Liège, Belgium, July 17-22, 2016.

[28] Akkari, C. (2015), Adaptation of Agriculture to Climate Change in Québec: The Co-construction of Agricultural Policies in the RCM of Haut-Richelieu. Département de Géographie, Université de Montréal, Canada, MSc thesis, pp. 153.
[29] Bousbaine, A. D., Bryant, C. R. (2016), Can the co-construction of projects with environmental externalities be an alternative to Environmental Mediation? In: Choquette, C. and Fraser, V. (editors), Environmental mediation: Diversity of practices across the world, Routledge, United Kingdom. (in press)

[30] Akkari, C. Bryant, C. R. (2016), The coconstruction approach to developing adaptation strategies in the face of climate change and variability: A conceptual framework, Agricultural Research, 2016, vol. 5, issue 2, Springer, The Netherlands, pp. 162-173.

[31] Akkari, C., Bryant, C.R., Marois, C. (2017), The co-construction of agricultural policies as a bottom-up adaptation strategy to climate change and variability (CCV) in the Regional County Municipality (RCM) of Haut-Richelieu, Québec. Journal of Agricultural Studies, [S.l.], Vol. 5, Issue n. 2, p. 141-162. Available at: http://www.macrothink.org/journal/ index.php/jas/article/view/11455. Last accessed: August 17, 2017. doi: http://dx.doi.org/10.5296/ jas.v5i2.11455.

[32] *** UNFCCC (United Nations Framework Convention on Climate Change), (2015), Available at: http: //www.cop21paris.org/about/cop21. Last accessed: August 17, 2017. 